\title{
Correlation amongst Indoor Air Quality, Ventilation and Carbon Dioxide
}

\author{
N. L. Sireesha* \\ Department of Architecture, School of Planning and Architecture, Jawaharlal Nehru Fine arts and \\ Architecture University, Hyderabad, Telangana, India
}

Received 12 January 2017, accepted in final revised form 2 April 2017

\begin{abstract}
The calculation of carbon dioxide $\left(\mathrm{CO}_{2}\right)$ intensities can be employed to see the quality of indoor air and ventilation. The studies undertaken till date have been distorted. The current study summaries the association amongst carbon dioxide and building air quality and ventilation, with carbon dioxide being the marker to evaluate air quality and ventilation performance. High carbon dioxide intensities may show insufficient ventilation per occupant and high indoor contaminants intensities, resulting in the Sick Building Syndrome (SBI) Symptoms. The researcher assessed the literature related to indoor air quality (IAQ), ventilation, and building-linked health issues in schools linked to $\mathrm{CO}_{2}$ discharges and recognised general indicated building-linked well-being signs found in schools. A high rise in the ventilation rate or enhancement in ventilation efficacy and/or indoor contaminant source regulation would be anticipated to reduce the occurrence of chosen signs to its optimum.
\end{abstract}

Keywords: Indoor air quality; Schools; Carbon dioxide; Ventilation; Health.

(C) 2017 JSR Publications. ISSN: 2070-0237 (Print); 2070-0245 (Online). All rights reserved. doi: http://dx.doi.org/10.3329/jsr.v9i2.31107 J. Sci. Res. 9 (2), 179-192 (2017)

\section{Introduction}

In the advanced world, over ninety percent of our lives rely on the quality of indoor air found in our homes, at the places where we work and in vehicles. The technological developments made in the developed countries have almost eradicated the influence of climate on people; people have successfully developed artificial climates that permit them to spend a long time indoors. Thanks to the artificial, automated climate control, people can live at any location cross the globe; however we are exposed to the quality of indoor air that we develop. Usually, the indoor air quality shares a direct association to the outdoor air quality, which enhances as people shift closer to large amount of vegetation and far away from the urban zones. The air is purified by the natural procedure of photosynthesis in vegetation since carbon dioxide is used by plants that release oxygen in the air.

\footnotetext{
*Corresponding author: nlsireesha@gmail.com
} 
Sadly, it is not realistic to provide adequate indoor vegetation in all the buildings especially to purify the indoor air sufficiently. Hence, the air we respire is frequently discovered to be of inferior quality and/or dangerously polluted. Unseen to the human eyes, these pollutants comprise of living and non-living objects including gases, fibres, dust, and microbes. Also almost fifty percent of their waking hours are spent by children in their schools. Thus, sustaining sufficient indoor air quality (IAQ) in schools is becoming important for both facility managers and building operating engineers. A crucial aspect for sustaining sufficient indoor air quality is outside air to reduce indoor air contaminants and consume these pollutants in addition to the moisture and smells from the buildings.

Over-exposure to the optimum outdoor contaminant levels as set by the National Ambient Air Quality Standards, United States Environmental Protection Agency in the year 1997, is a crucial issue for children and people of old age. Since children breathe a higher air volume compared to adults in context to their body weight, the danger to the children is higher in such settings. The body stress of the toxin contaminants is much more for smaller children compared to the adults in settings that similar in character. Compared to an adult's breathing area, the number of contaminants present in a child's breathing area is much more. There is a great impact of the $\mathrm{CO}_{2}$ concentration over the decision making and cognitive thinking of humans as disclosed from the new investigations from Harvard School of Public Health. These effects are direct and negative to the aforementioned activities. The research was performed on American citizens and their children going to schools, offices, home, cars, planes, classrooms etc. The indoor $\mathrm{CO}_{2}$ concentrations are inescapably higher than the outdoor air for ventilations. The main reason behind this continuously increasing baseline of $\mathrm{CO}_{2}$ concentrations are the various activities like burning of the fossil fuels performed by humans in their everyday life. These activities have become essential and inevitable part of our lives. The results of this research are significant for the climatic policies also giving a new impetus for public health in order to control and maintain the global $\mathrm{CO}_{2}$ concentration level reduced [1]. The degree of $\mathrm{CO}_{2}$ in an air sample is commonly articulated to be as per million (ppm). The outdoor air in majority of the places has around 380 parts per million (ppm) of carbon dioxide. In areas with heavy vehicular traffic, areas where industries or located or places wherein there are sources of combustion, the outdoor air contains a higher level of $\mathrm{CO}_{2}$ intensities. In areas where indoor intensities are higher (contrast to the external air), the cause is attributed to the occupants in the building. Individuals breathe out carbon dioxide - the mean adult's breath has around 35,000 to 50,000 ppm of $\mathrm{CO}_{2}$ (100 times higher than outdoor air). In the absence of sufficient ventilation to reduce and eliminate the $\mathrm{CO}_{2}$ that is consistently being thrown out by the occupants, $\mathrm{CO}_{2}$ can gather and its intensity becomes stronger. The extant technology permits simple and comparatively cheaper calculation of $\mathrm{CO}_{2}$ as a marker to facilitate that the ventilation systems (for high density occupancy zones) are providing the suggested minimum quantities of outside air to the building's occupants. 
The intensities of $\mathrm{CO}_{2}$ found in most schools are much below the 5,000 ppm occupational safety criteria (time weighted mean for an eight-hour workday in a $40 \mathrm{hr}$ work week) for an industrial place of work. While levels below 5,000 ppm are not regarded to have any dangerous risks to the well-being, experience shows that individuals in schools with higher $\mathrm{CO}_{2}$ intensities are likely to complain about drowsiness, tiredness and an overall feeling of the air not being fresh.

\subsection{General air contaminants present in schools}

The majority part of children is spent in the school environment. There are various factors which exhibit great impact on the indoor environmental quality of school. The factors are: location or locality of school, the condition of the school building, its regular cleaning (neat and tidy campus) and maintenance. Apart from these there are various pollutants whose presence also influences and exhibits impacts on the indoor quality like presence of bacteria, moulds etc. Whereas, the main air contaminants characteristic present in school comprises of environmental tobacco smoke, formaldehyde, volatile organic compounds, nitrogen oxides, carbon monoxide, carbon dioxide, allergens, pathogens, radon, pesticides, lead, and dust [2,3]. Further, detailed descriptions are:

- Environmental tobacco smoke (ETS) is the amalgamation of two kinds of smoke from burning tobacco products: side stream smoke, (smoke that is emitted between the puffs of a burning cigarette, pipe, or cigar), and conventional smoke (the smoke that is respired by the smoker.)

\section{Indoor Air Pollutant Flow}

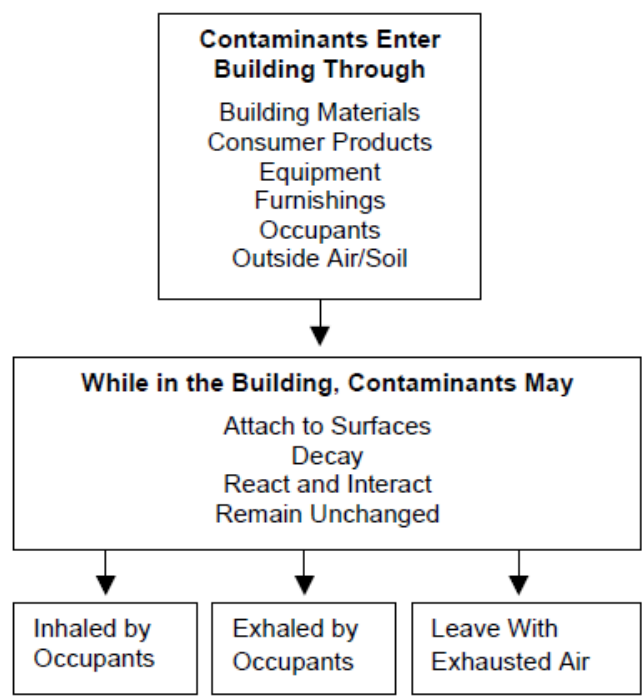

Fig. 1. The indoor air contaminant sources, and their outcome in the building setting.

Source: School Indoor Air Quality. Best Management Practices Manual, November, 2003. [4]. 
- Sources such as particleboard, plywood, textiles, adhesives, foam insulation, and pressed wood furniture, cabinets and shelving release formaldehyde.

- Sources like generally-utilised cleaners, personal care products, adhesives, paints, pesticides solvents, wood preservatives, furnishings, and copying machines discharge explosive organic compounds.

- The procedure of combustion, welding, and tobacco smoke releases nitrogen oxide.

- The partial combustion or unvented gas, kerosene heaters, boilers, furnaces, auto, truck, and bus exhaust releases carbon monoxide.

- All the combustion procedures and human metabolic procedures release carbon dioxide.

- Humans, animals, the environment, draperies, carpet, dust collecting sources, cooling towers, dirty cooling coils, humidifiers, condensate drains, and ductwork, which can gestate bacteria and moulds release allergens and pathogens.

- The earth around some buildings, well water, and even few masonry blocks release radon.

- Pesticides put close to the building can be pulled indoors, contaminating the indoor environment.

The soil, fleecy surfaces, and pollen, burning wood, oil, or burning coal [5] releases dust.

\section{Rates of Ventilation and $\mathrm{CO}_{2}$ Intensities in Schools}

Schools have very rarely calculated the ventilation rates, despite insufficient ventilation alleged to be a crucial criterion resulting in documented well-being signs [6] suggests at least a ventilation rate of $8 \mathrm{~L} / \mathrm{s}$-person $(15 \mathrm{cfm} /$ person) for classrooms. Considering the usual occupant density of 33 per $90 \mathrm{~m}^{2}\left(1000 \mathrm{ft}^{2}\right)$ and the ceiling height to be around $3 \mathrm{~m}$ (10 ft.), the present SHRAE criterion would need an air exchange rate of around 3 air changes per $\mathrm{hr}(\mathrm{ACH})$ for a classroom. Three researches were conducted in schools that did not comply with the above criterion. Some researches offered only the average data while others have details for individual schools. Some data were for the same schools under varied settings like before and after radon alleviation. A study by Turk et al. [7] discussed ventilation calculations made in 6 schools that did not follow the norms located in the U.S. Northwest-2 in Portland, OR and 4 in Spokane, WA. The age of the schools varied from 3 years to 25 years with 1 to 3 stories. All the schools spoke about automatic ventilation systems of some kind. Ventilation rates, gauged on the entire building volume basis, varied from $4.5 \mathrm{~L} / \mathrm{s}$-person to $31 \mathrm{~L} / \mathrm{s}$-person. The entire or aggregate building rate, on the other hand, comprises of places that are vacant including the hallways and gymnasiums, and as indicated by the researchers, this aggregate rate miscalculates the domestic ventilation rate of classes that are vacant. For instance, in one of the elementary schools, the ventilation rate of the entire building was $4.5 \mathrm{~L} / \mathrm{s}-$ person while in the occupied classrooms, the ventilation rate was merely $1.6 \mathrm{~L} / \mathrm{s}$-person. Turk et al. [8] also stated that ventilation rates calculated in 2 schools located in Sante Fe, NM, were being alleviated for high radon intensities. Twelve before and after radon alleviation ventilation 
rates were reported to be less than $3 \mathrm{ACH}$ with one school being the sole exclusion. According to Nielsen [9], ventilation calculations were made in 11 randomly chosen schools in Denmark. The calculations were taken in 2 classrooms for 3 sequential days. The mean ventilation rate was discovered to be $6.4 \mathrm{~L} / \mathrm{s}$-person with a span of $1.8-15.4$ L/s-person.

\section{1. $\mathrm{CO}_{2}$ and $\mathrm{SBS}$ researches in the literature}

A latest appraisal indicated that around fifty percent out of 22 researches related to the Sick Building Syndrome (SBI) signs in office buildings indicated that enhanced indoor $\mathrm{CO}_{2}$ intensities were affirmatively linked with a statistically crucial rise in the occurrence of a single or more than a single SBS sign. SBS signs linked with $\mathrm{CO}_{2}$ comprised of tiredness, headaches, issues with the eyes, nose, issues with the respiratory tract, and entire sign scores. Seventy percent of researches of automatically ventilated and air conditioned buildings discovered to have a crucial link amongst a rise in $\mathrm{CO}_{2}$ and SBS signs. Building ventilation was also linked with SBS signs.

\section{2. $\mathrm{CO}_{2}$ intensities}

The intensities of $\mathrm{CO}_{2}$ are frequently employed as a substitute of the rate of outside supply air per occupant. Indoor $\mathrm{CO}_{2}$ intensities that surpass around $1000 \mathrm{ppm}$ are usually considered to indicate that the ventilation rates are offensive in context to body smells. Intensities of $\mathrm{CO}_{2}$ below $1000 \mathrm{ppm}$ do not always ensure that the ventilation rate is sufficient for eradication of air contaminants from other indoor sources [10]. It is tough to sufficiently typify indoor $\mathrm{CO}_{2}$ intensities as they are calculated based on occupancy and ventilation rate, both differing as a function of time. Grab samples or other short-run calculations may be insufficient to offer details on the long-run ventilation settings in the schools. There is a large unpredictability in the techniques employed to typify the indoor $\mathrm{CO}_{2}$ intensities in the studies analysed subsequently. The mean and spans of $\mathrm{CO}_{2}$ intensities indicated in the scientific literature for U.S. and Canadian schools, and for European schools, correspondingly, for both schools that meet or fail to meet the criterion are indicated in Figs. 2 and 3 subsequently. In several of the reports, intensities are close to or merely little higher than the ASHRAE criterion of $1,000 \mathrm{ppm}$, irrespective of condition whether they are conforming or non-conforming. $\mathrm{CO}_{2}$ intensities that exceed $1000 \mathrm{ppm}$ were also seen in few non-conforming schools. Brennan et al. [11] undertook mid-afternoon $\mathrm{CO}_{2}$ calculations in a non-random research of 9 U.S. non-conforming schools. Intensities differed from around 400 to $5,000 \mathrm{ppm}$ (mean $=1480 \mathrm{ppm}$ ). $\mathrm{CO}_{2}$ intensities varied from around 400 to $5,000 \mathrm{ppm}($ mean $=1480 \mathrm{ppm})$. Ina round $74 \%$ of the schools, the $\mathrm{CO}_{2}$ intensities surpassed the $1000 \mathrm{ppm}$ ASHRAE ventilation criterion. The aggregate the $\mathrm{CO}_{2}$ intensities for 3 non-conforming schools in Alberta, Canada were less than $1000 \mathrm{ppm}$ despite few calculations surpassing this intensities [12]. The aggregate $\mathrm{CO}_{2}$ intensity in one portable classroom stood at $1950 \mathrm{ppm}$. The number of classrooms analysed in all schools were not given. According to Turk, et al. (1993), little high $\mathrm{CO}_{2}$ 
intensities for two schools in New Mexico before to and post the radon elimination. Fisher et al., and Thorne [13] indicate comparable enhanced indoor $\mathrm{CO}_{2}$ intensities before radon being eliminated, with lowering to levels less than $1000 \mathrm{ppm}$ after the elimination of $\mathrm{CO}_{2}$ intensity calculations indicated for several of the mon-conforming European Schools were almost equal to or more than $1000 \mathrm{ppm}$. According to Lasovic et al. [14], the researcher tested the $\mathrm{CO}_{2}$ concentration level in two Schools, in the first School $\mathrm{C}$ the mean outdoor $\mathrm{CO}_{2}$ concentration level was $424 \mathrm{ppm}$ and $575 \mathrm{ppm}$ in HS and NHS respectively. For the second School D, the mean outdoor $\mathrm{CO}_{2}$ concentration level was $524 \mathrm{ppm}$ and $608 \mathrm{ppm}$ in HS and NHS respectively. It was previously reported that $1000 \mathrm{ppm} \mathrm{CO}_{2}$ concentration in the indoor environment in accordance with body odours are not accepted. Two Swedish Schools [15] had a mean intensity of 1420 and $1850 \mathrm{ppm}$. Median $\mathrm{CO}_{2}$ intensities stood at $1070 \mathrm{ppm}$ (range 800 to $1600 \mathrm{ppm}$ ) in a research of 10 Swedish non-conforming Schools, and $1100 \mathrm{ppm}$ (range 875 to $2150 \mathrm{ppm}$ ) in 11 schools with higher occurrence of SBS signs [16]. Nielsen et al. discussed a measurement that indicated a $\mathrm{CO}_{2}$ range of around $500-1500 \mathrm{ppm}$ (average $=1000 \mathrm{ppm}$ ) in 11 Danish schools. Several of the European calculations used colorimetric indicator tubes over a small time span. Potting, et al. [17] recounted an epidemiological research that included 339 students in 3 Dutch complaint schools (14 classrooms) and 4 schools that had no teacher grievances (207 controls). All these schools were built after 1980. During 27 to $97 \%$ of the school time, the $\mathrm{CO}_{2}$ intensity in all the classrooms surpassed the Dutch criterion of $1200 \mathrm{ppm}$. The levels in one classroom was more than $2500 \mathrm{ppm} \mathrm{CO}_{2}, 73 \%$ of the time while the level of $\mathrm{CO}_{2}$ stood at $1100 \mathrm{ppm}$ in another room, when the school began during the day. Smedje et al. $[18,19]$ recounted the mean and ranges of indoor $\mathrm{CO}_{2}$ intensities for 96 classrooms in 38 Swedish schools that were chosen randomly from a populace of 130 schools; $61 \%$ of these schools boasted of automatic supply and exhaust air systems while the rest had natural ventilation. The intensities were aggregated to be around $990 \mathrm{ppm} \mathrm{CO}_{2}$ for 38 schools, but surpassed $1000 \mathrm{ppm}$ for $41 \%$ of the calculations (maximum $=2800 \mathrm{ppm}$ ).

Overall, $\mathrm{CO}_{2}$ calculations in schools recommend a crucial ratio of classrooms is likely not to fulfil the ASHRAE Standard 62-1999 for minimum ventilation rate, at least sometimes. Additionally, despite there being limited data it seems that this scenario may be more severe in portable classrooms. This remark is endorsed by different ventilation rate calculations. There is no validation to recommend that higher $\mathrm{CO}_{2}$ intensities were limited to schools that have grievances. On the other hand, there have not been any symbolic investigations of school classrooms to offer details on the circulations of $\mathrm{CO}_{2}$ intensities or ventilation rates in schools or across the state, regional or across the country too. Intensities of different contaminants discharged by the occupants and building materials and fittings will be more under these settings than if the ASHRAE ventilation criterion were fulfilled. Special emphasis needs to be given to the possibility of enhanced danger of catching specific infectious respiratory sicknesses, like the flu and common colds in classrooms with reduced ventilation rates [20].

Carbon dioxide is not the sole challenging source of inferior air quality in school buildings. Well-being issues between the students and teachers will lead to the increase of 
illnesses and leaves for falling sick, inferior student involvement and attainment. It is remarkable to think that a gradual rise in carbon dioxide may result in such big issues for both teachers and students in the school.

\subsection{Causes for inferior indoor air quality}

The main causes for inferior indoor air quality include insufficient ventilation, ineffective filtration, and inferior hygiene of air handling units. These shortages are damaging to providing superior indoor air quality, particularly in schools. The American Society of Heating, Refrigerating and Air-conditioning Engineers (ASHRAE) suggest the Standard 62-1999, Ventilation for Acceptable Indoor Air Quality [21] as mentioned subsequently in table no.1.

Table 1. Acceptable Ventilation IAQ as given by ASHRAE

\begin{tabular}{llc}
\hline & Application/Area & $\begin{array}{c}\text { CFM* per person } \\
\text { CFM cubic feet per minute }\end{array}$ \\
\hline 1 & Classrooms & 15 \\
2 & Music Rooms & 15 \\
3 & Libraries & 15 \\
4 & Auditoriums & 15 \\
5 & Spectator Sport Areas & 15 \\
6 & Playing Floors & 20 \\
7 & Office Spaces & 20 \\
8 & Conference Rooms & 20 \\
9 & Cafeteria & 20 \\
10 & Kitchen (Cooking) & 20 \\
11 & Patient Rooms & 20 \\
\hline
\end{tabular}

\subsection{Suggested criteria for satisfactory ventilations}

There are different criteria and norms described by schools for the ventilation rates. The American Society of Heating, Refrigeration, and Air Conditioning Engineers [9] Standard 62 is the most preferred criterion. There are some states and local codes that have espoused the ASHRAE Standard 62 ventilation needs. As per ASHRAE Standard 62, classrooms need to have 15 cubic feet per minute ( $\mathrm{cfm}$ ) outside air per person, and offices need to be provided with $20 \mathrm{cfm}$ outside air per person. ASHRAE has also provided ventilation rates for other indoor locations. The rates may alter since the Standard 62 is presently being modified. According to ASHRAE, indoor $\mathrm{CO}_{2}$ intensities need to be sustained at or be below 1,000 ppm in schools (refer to the subsequent chart) employing $\mathrm{CO}_{2}$ as a marker of ventilation. It is suggested by ASHRAE that indoor $\mathrm{CO}_{2}$ intensities must not surpass the outdoor focus by over $600 \mathrm{ppm}$.

The association amongst $\mathrm{CO}_{2}$ levels and outside air ventilation rate can be seen by the Table no:2, when outdoor $\mathrm{CO}_{2}$ is around $350 \mathrm{ppm}$ [22]. 


\subsubsection{Ventilation and ensuing $\mathrm{Co}_{2}$ intensities}

Table 2. Association amongst $\mathrm{CO}_{2}$ levels and outside air ventilation rate.

\begin{tabular}{lll}
\hline Carbon dioxide & Outside air (cfm per person) & $\begin{array}{l}\mathrm{CO}_{2} \text { differential } \\
\text { (inside/outside) }\end{array}$ \\
\hline 800 ppm recommends around & $20 \mathrm{cfm}$ (or less) & $500 \mathrm{ppm}$ \\
$1,000 \mathrm{ppm}$ recommends around & $15 \mathrm{cfm}$ (or less) & $650 \mathrm{ppm}$ \\
$1,400 \mathrm{ppm}$ recommends around & $10 \mathrm{cfm}$ (or less) & $1,050 \mathrm{ppm}$ \\
$2,400 \mathrm{ppm}$ recommends around & $5 \mathrm{cfm}$ (or less) & $2,050 \mathrm{ppm}$ \\
\hline
\end{tabular}

Source: Rich Prill,"Why measure carbon dioxide inside the buildings" Washington State University Extension Energy Program, 2000

Remark: The Table 2 provides an estimated value of $\mathrm{CO}_{2}$ and depends on a consistent number of inactive adult occupants, a constant ventilation rate, an outdoor air $\mathrm{CO}_{2}$ intensity of about $380 \mathrm{ppm}$, and good mixing of the indoor air.

The levels of carbon dioxide in adequately ventilated buildings should be around 600 ppm and 1,000 ppm, with a floor or building mean of 800 ppm or less. If the mean carbon dioxide levels within a building are sustained at less than $800 \mathrm{ppm}$, with rough temperature and humidity levels, grievances related to indoor air quality would be mitigated. If the carbon dioxide levels exceed than $1,000 \mathrm{ppm}$, people may raise grievances.

Thus, 1,000 ppm needs to be employed as a directive for enhancing ventilation. If a building surpasses the directive, it must not be inferred to be a dangerous or lifeintimidating scenario. A higher carbon dioxide level is merely a sign of insufficient amount of external air being circulated inside the building. Carbon dioxide is a standard element of respired breath and is generally calculated as an inspection mode to assess if sufficient volumes of fresh outdoor air are being advanced into the indoor air. The outdoor level of carbon dioxide generally ranges from 300 to $400 \mathrm{ppm}$. The level of carbon dioxide level inside a building is usually higher compared to outside the building, even in buildings that have limited grievances pertaining to quality of indoor air. If the indoor carbon dioxide levels surpass $1,000 \mathrm{ppm}$, there is a chance of insufficient ventilation and grievances including headaches, tiredness and eye and throat inflammation may become common. One must note that carbon dioxide per sec cannot be held liable for these grievances; a high level of carbon dioxide, on the other hand, may show that other pollutants in the building also exist at high levels and may be accountable for the grievances given by the occupants. 


\section{Main symptoms of \\ Carbon dioxide toxicity}

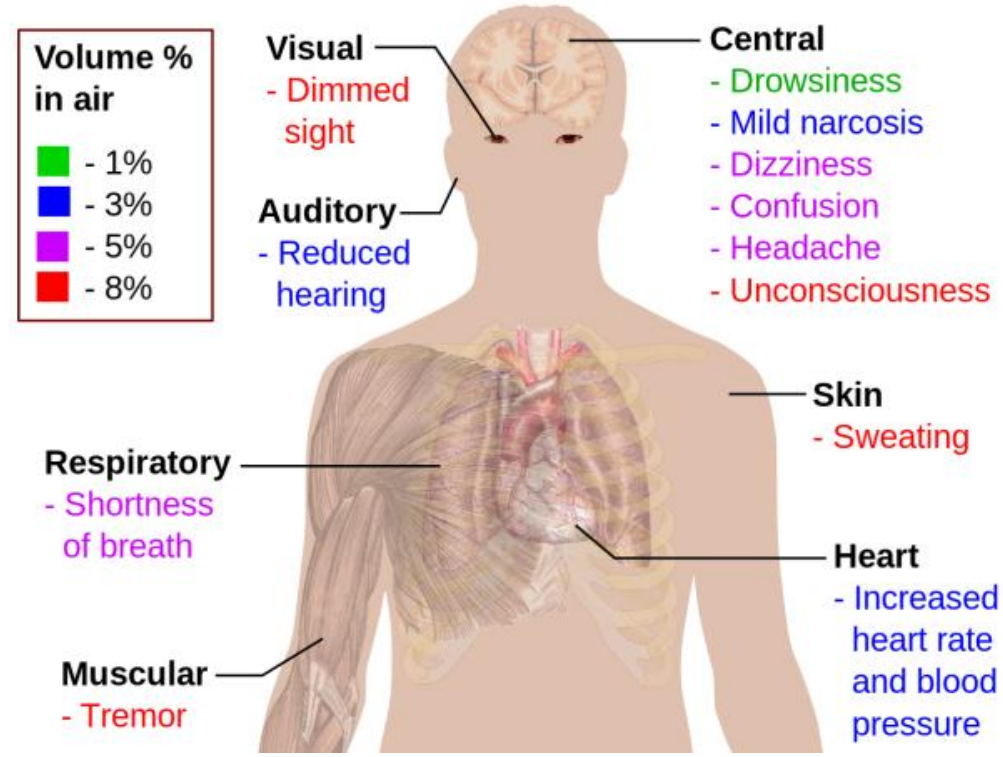

Fig. 2. Carbon dioxide and its effects on Human body

Source: Indoor air quality in schools affects grades. By Sarah Croft[23]

The directives above are not useful in building zones where there are likely sources of carbon dioxide beyond the respired breath. Other sources comprise of exhaust gas from kilns, internal combustion engines, dry ice, etc. Under such settings, the Occupational Safety and Health Administration (OSHA) criterion for carbon dioxide is applicable. The OSHA criterion stands at an eight-hour time-weighted average (TWA) of 5,000 ppm with a short-term 15-minute average limit of 30,000 ppm.

\section{Present Technology and IAQ}

Presently, the calculation of carbon dioxide is a crucial method to facilitate sufficient outside air ventilation while at the same time, save energy by lowering the number of over-ventilated buildings. Technological advancements have allowed people to employ comparatively cheaper $\mathrm{CO}_{2}$ sensors to consistently keep a check on the levels of $\mathrm{CO}_{2}$ in a building. These $\mathrm{CO}_{2}$ values can be utilised by the heating, ventilation and air-conditioning (HVAC) control system to repeatedly regulate the volume of outside air to sustain indoor $\mathrm{CO}_{2}$ at or below a pre-decided intended intensity. This policy is referred to as demand controlled ventilation (DCV). DCV systems are particularly beneficial for those areas or places that boast of variable occupancy rates: the ventilation rate reacts correspondingly to modifications in the density of occupation [24]. The subsequent Table indicates (Table 3) the well-being impacts that a result of the building up of $\mathrm{CO}_{2}$ in a setting and the equivalent regulatory methods. 
A study undertaken by Scheff, Paulius, Huang and Conroy [25] related to indoor air quality in middle school employed $\mathrm{CO}_{2}$ as a marker for efficient ventilation. The emphasis of the research was on the association amongst occupancy and the gauged intensities of carbon dioxide in addition to an assessment of the utilisation of carbon dioxide as a marker for ventilation in the school. The school was typified to be one with no health conditions, adequate maintenance schedules; carpets were absent both in the hallways and the classrooms; further there was no major remodelling that was undertaken. The sampling was conducted when the classes were on. The sample locations for different environmental comfort and contaminant criteria included the cafeteria, a science classroom, an art classroom, and the lobby outside the main office, and one outdoor space consistently for seven days in February 1997. A constant link amongst hourly occupancy and equivalent carbon dioxide intensities were observed. The intensities of carbon dioxide in the cafeteria, art room, and lobby were found to be as per the directives of American Society of Heating, Refrigerating, and Air-Conditioning Engineers (ASHRAE) for comfort (< $1000 \mathrm{ppm})$. It was seen that highest intensities of carbon dioxide (often surpassing $1000 \mathrm{ppm}$ ) existed in the science room mainly due to the high occupancy and defunct unit ventilators. It was discovered that in the art room, cafeteria and the lobby, the calculated ventilation rates fulfilled the criteria provided by ASHRAE. It was solely the science room that failed to fulfil the ASHRAE criteria on one of the three days evaluated as it depended purely on natural ventilation. Thus, the research indicated the benefit of gathering indoor $\mathrm{CO}_{2}$ and occupancy data when researchers examined the indoor air quality in schools.

Table 3. Well-being Impacts of $\mathrm{CO}_{2}$ in setting along with regulatory techniques.

\begin{tabular}{|c|c|c|c|}
\hline Contaminant & Sources & Impact on Comfort and well-being & $\begin{array}{l}\text { Regulatory } \\
\text { Techniques }\end{array}$ \\
\hline $\begin{array}{l}\text { Carbon } \\
\text { dioxide is a } \\
\text { gas that has } \\
\text { no color, odor } \\
\text { or taste. It is } \\
\text { the result of } \\
\text { carbon } \\
\text { combustion } \\
\text { process being } \\
\text { completed. }\end{array}$ & $\begin{array}{l}\text { The sources of } \\
\text { carbon dioxide } \\
\text { include all } \\
\text { combustion } \\
\text { procedures. } \\
\text { Intensities of } \\
\mathrm{CO}_{2} \text { from } \\
\text { individuals are } \\
\text { extant in } \\
\text { buildings that } \\
\text { are occupied. }\end{array}$ & $\begin{array}{l}\text { Carbon dioxide is an ingenuous gas that } \\
\text { suffocates. At intensities that surpass } \\
1.5 \% \text {, it becomes difficult to inhale and } \\
\text { exhale. If the intensity surpasses } 3 \% \mathrm{CO}_{2} \\
\text { leads to one feeling nauseous, having } \\
\text { headaches and causes dizziness. If the } \\
\text { intensity of } \mathrm{CO}_{2} \text { is around } 6 \% \text { to } 8 \% \text {, it } \\
\text { may lead to numbness and even death. At } \\
\text { reduced intensities ( } 0.1 \text { percent), people in } \\
\text { the building may suffer from headaches, } \\
\text { tiredness, eye or respiratory tract } \\
\text { inflammation. At reduced intensities, the } \\
\text { buildup of } \mathrm{CO}_{2} \text { shows insufficient. }\end{array}$ & $\begin{array}{l}\text { Aerate with } \\
\text { fresh air to } \\
\text { regulate the } \\
\text { levels of } \\
\text { carbon dioxide. } \\
\text { The rate of } \\
\text { ventilation } \\
\text { must fulfill the } \\
\text { WAC 51-13. } \\
\text { This needs } 15 \\
\text { CFM/person in } \\
\text { a characteristic } \\
\text { classroom. }\end{array}$ \\
\hline
\end{tabular}

Source: School Indoor Air Quality. Best Management Practices Manual, November, 2003. 


\subsection{Assessment of performance loss (EPA 402-F-00-009)}

An EPA article [26,27] provides the subsequent inferences:

- A research was undertaken in Europe, including 800 students from eight varied schools, to gauge student performance linked to the indoor air quality.

- The gathered data showed health issues and the skill of the student to focus as linked to $\mathrm{CO}_{2}$ calculations in the classroom.

- A health questionnaire was handed out to the students; this recorded the data following which a computer-based program was used to rank their skill to focus.

- It was discovered that the students' ranking were low in those classrooms that had high levels of $\mathrm{CO}_{2}$ (low ventilation rates); further, their health signs in such classrooms were also very high.

- The data inferred that inadequate quality of IAQ would lower the skill of a person to execute particular mental jobs which needed focus or calculation or memory.

- There was statistical importance accorded to these tests and they validated that managing IAQ encompassed regulating the source and providing sufficient ventilation which in turn, enhanced the performance of the students.

- It is the exhaled breath that is the primary source of $\mathrm{CO}_{2}$ and ventilation is the fundamental method to eradicate the same. Low rates of ventilation are clearly indicated by high levels of $\mathrm{CO}_{2}$ in classrooms. This can be corrected by suitable checking the $\mathrm{CO}_{2}$ levels which consequently provides the zone good quality of indoor air.

\subsection{The relationship between functioning and ventilation}

Two analyses lately conducted have validated the link between student attendance, classroom performance and ventilation. The first research by Shendell et al. [28], recorded the links amongst classroom attendance in Washington and Idaho and $\mathrm{CO}_{2}$ intensities, which were employed as a substitute for ventilation rates. Student absences were discovered to be $10 \%-20 \%$ higher for classrooms where the variation between indoor and outdoor $\mathrm{CO}_{2}$ intensities surpassed $1000 \mathrm{ppm}\left(1800 \mathrm{mg} / \mathrm{m}^{3}\right)$, in contrast to classrooms where the variations in $\mathrm{CO}_{2}$ intensities was less than $\left(1800 \mathrm{mg} / \mathrm{m}^{3}\right)$. The next research [29] analysed the performance in school in a regulated classroom scenario in Denmark where in there was a difference in the ventilation and temperature. The intensity of $\mathrm{CO}_{2}$ production using non-dispersive $\mathrm{IR} \mathrm{CO}_{2}$ logger for the measurement of different condition like the physical and the mental stress, relaxation for a particular school buildings were measured. The measurement of the $\mathrm{CO}_{2}$ production for mental stress is $24 \%$ higher and physical stress is 2.5 times higher than compared to the relaxation levels. The $\mathrm{CO}_{2}$ concentration is found to be $2100 \mathrm{ppm}$ when the classes were ventilated between the classes. Further, the mental concentration levels were tested for the seventh grade school students with varying $\mathrm{CO}_{2}$ concentrations and the results revealed that when the students were provided with the five letter words anagrams under $1000 \mathrm{ppm}$ and above $2000 \mathrm{ppm}$ 
concentrations of $\mathrm{CO}_{2}$, the number of correct answers reduced and the number of errors increased when the concentration of $\mathrm{CO}_{2}$ level were above $2000 \mathrm{ppm}$ [30]. The concentration levels of $\mathrm{CO}_{2}$ were measured in primary school classrooms in Scotland. The measurement was done in 60 classrooms over a period of 3-5 days. This test was performed regarding the annual attendance, socio-economic status and the size of class room. The results indicated that the decreased attendance as well as health issues of students were related to $\mathrm{CO}_{2}$ concentration levels above $1000 \mathrm{ppm}$ [31]. According to the researchers, a rise in the supply rate of outdoor air and lowering of somewhat higher classrooms radically enhanced the performance of several tasks, chiefly in context of how fast every student could work (speed) in addition to few tasks in context of how many mistakes were made ( $\%$ mistakes, the ratio of replies that were mistakes). The enhancement was statistically important at the level of $\mathrm{P} \leq 0.05$.

\section{Discussion}

It is difficult to plan and develop suitable environments for air quality and air quantity as air is undetectable. $\mathrm{CO}_{2}$ levels accord adequate information related to indoor air quality. Examining the $\mathrm{CO}_{2}$ levels is essential to identify the indoor air quality in any zone. The need is magnified, when the area is a teaching area, particularly where it has an early childhood learning setting, mainly because the young kids are more vulnerable to the impacts of bad indoor air quality. Planners who know about IAQ issues will always design spaces that permit higher values of CFM (cubic feet per minute) than what is needed to ensure that ventilation levels exceed the agreed criteria. Designers during the 1960's generally planned spaces that allowed an indoor air rate of 30 CFM per individual; this reduced to 5 CFM when dealing with the energy predicament in the initial 1970's. This figure has presently been amended to 15 CFM. The systems and spaces are required to be planned in a manner that they attain the higher values as required by the children. Creative planners would be pre-emptive in using higher ventilation rates to guarantee that the space provides the highest possible quality of indoor air. Examining the levels of $\mathrm{CO}_{2}$ is essential to sustain high quality of indoor air in the classroom.

The extant calculations of ventilation rates and $\mathrm{CO}_{2}$ concentrations in schools indicate that, if we depend on the present ASHRAE ventilation criteria, several classrooms are insufficiently ventilated. Despite, the outcomes from some of the researches in schools being unreliable in linking ventilation rates or $\mathrm{CO}_{2}$ concentrations and signs; an extensive literature assessment for indoor environments overall recommends a reliable association [32]. These inferences, mainly in the grown-ups, would also relate to school children with two justifiable postulations: that the exposures in offices linked to ventilation rates are akin to exposures in the schools, and that the children are at least as susceptible as adults to such exposures. The inferences made by Seppanen et al., together with the information related to ventilation insufficiency in present schools, soundly recommend a pervasive environmental insufficiency in schools is most probably linked to enhanced illnesses. Hence, techniques to regulate encompass using proper fixtures and finish materials to 
keep contamination sources outside the school building, utilising exhaust fans to seize and eradicate contaminants, and regulating pressures amongst areas to limit the migration of contaminants to occupied or delicate domains. According to the good practices, it is recommended that one needs to eliminate, eradicate and also mitigate contaminants that allegedly have the possibility to lead to well-being issues or impact functioning and relaxation.

\section{Conclusion}

The present study makes it evident that there is limited information pertaining to IAQ in schools. The sole exclusion is the initial National Institute for Occupational Safety and Health (NIOSH) analysis that is not even mentioned in the literature assessed; furthermore no other studies have consistently analysed IAQ and health results in the schools. Several of the researches have overlooked the thoroughness and quality that was essential to handle the issue. There was a requirement to undertake more studies that analysed the correlation amongst indications and that gauged exposures to several particular contaminants. Additionally, there was a need to collect quantitative data relating to exposure-well-being answer associations for particular contaminants that allegedly result in well-being indicators, so as to offer a robust base to develop criteria for schools and to ensure reasonably priced improvement methods. There is a requirement for enhanced techniques for calculating exposure, especially those that offer more details of fungi and bacteria and extended time for conducting the sample studies. The degree of the issue still remains unidentified despite it being proved that several schools have insufficient ventilation.

There is a need to meticulously and carefully gauge the ventilation rates and/or $\mathrm{CO}_{2}$ levels in a symbolic sample of schools; this would offer the essential details required on the sections of schools dealing with the issue. To conclude, despite more research required to ascertain the degree of IAQ issues in schools, it is proved that the ventilation rates in new and extant schools fails to even meet the bare minimum ASHRAE criteria; this is the cause for a crucial rise in signs amongst both school teachers and school children. It is evident that programs need to be initiated to guarantee that much needed ventilation is offered by all the schools.

\section{References}

1. J. Romm, Elevated $\mathrm{CO}_{2}$ Levels Directly Affect Human Cognition, Climate Progress, Oct 26 (2015).

2. Z. Zhao, Z. Zhang, Z. Wang, M. Ferm, Y. Liang, and D. Norbäck, Environ Health Perspect, 116 (1), 190 (2008).

3. M. Turunena, O. Toyinboa, T. Putusb, A. Nevalainena, R. Shaughnessyc, and U. HaverinenShaughnessy, Int. J. Hyg. Environ. Health 217(7), 733 (2014). https://doi.org/10.1016/j.ijheh.2014.03.002

4. School Indoor Air Quality, Best Management Practices Manual (2003).

5. US EPA tools for Schools Action Kit (1995).

6. ASHRAE Standard 62-1999 (ASHRAE, 1999) 
7. Annabel Broome, Health Psychology: Processes and Applications (2013).

8. Clearing the Air: Asthma and Indoor Air Exposures, By Institute of Medicine, Division of Health Promotion and Disease Prevention, Committee on the Assessment of Asthma and Indoor Air (2000).

9. Energy Research Abstracts, Technical Information Center, U.S. Department of Energy (1985).

10. O. A. Seppanen, W. J. Fisk, and M. J. Mendell, Indoor Air 9, 226 (1999). https://doi.org/10.1111/j.1600-0668.1999.00003.x

11. Eric,"A Survey and Critical Review of the Literature on Indoor Air Quality, Ventilation and Health Symptoms in Schools. IEQ Strategies (1998).

12. Indoor Air Quality in 12 Schools: A Case Study, in The Human Equation: Health and Comfort - Proceedings of ASHRAE Conference IAQ'87, 104-108.

13. J. M. Daisly, W. J. Angell, and M. G. Apte, Indoor Air 13, 53 (2003). https://doi.org/10.1034/j.1600-0668.2003.00153.x

14. Ivan m. lazovia, žarko m. stevanovi]a, milena v. jovaševi-stojanovia, marija m. živkovia, and miloš j. banjac, Impact of $\mathrm{CO}_{2}$ Concentration on Indoor Air Quality and Correlation with Relative Humidity and Indoor Air Temperature in School Buildings in Serbia (2016).

15. D. Norback, Indoor Air 5, 237 (1995). https://doi.org/10.1111/j.1600-0668.1995.00003.x

16. I. M. Lazovi, Ž. M. Stevanovi, M. V. Jovaševi-Stojanovi, M. M. Živkovi, and M. J. Banjac, Thermal Sci. 20, S297 (2016). https://doi.org/10.2298/TSCI150831173L

17. Penny Webb, Chris Bain, "Essential Epidemiology: An Introduction for Students and Health Professionals" (2011).

18. G. Smedje, D. Norback, and C. Edling, Indoor Air 7, 143 (1997). https://doi.org/10.1111/j.1600-0668.1997.00009.x

19. G. Smedje, D. Norback, B. Wessen, and C. Edling, in Asthma among School Employees in Relation to the School Environment - Proceedings of Indoor Air '96: The 7th International Conference on Indoor Air Quality and Climate (Nagoya, Japan, July, 1996) 1, pp. 611-616.

20. W.J. Fisk, Indoor Air Quality Handbook, ed. J. Spengler et al. (McGraw Hill, New York, 2001).

21. ASHRAE Standard 62: Ventilation for Acceptable Indoor Air Quality (Atlanta, USA, 1992).

22. R. Prill, Why Measure Carbon Dioxide Inside the Buildings (Washington State University Extension Energy Program, 2000).

23. S. Croft, Illinois Department of Public Health Guidelines for Indoor Air Quality Indoor Air Quality in Schools Affects Grades.

24. IAQ Diagnostics Reference Manual: Hands-On Assessment of Building Ventilation and Pollutant Transport (Department of Chemical Engineering, College of Engineering and Applied Sciences, University of Tulsa).

25. P. A. Scheff, V. K. Paulius, S. W. Huang, and L. M. Conroy, Appl. Occup. Environ. Hyg. 15, 824 (2000). https://doi.org/10.1080/10473220050175706

26. EPA, Indoor Air Quality and Students Performance (2000).

27. D. Sundersingh, D. Bearg, PE, CIH," Indoor Air Quality in Schools: The importance of Monitoring Carbon Dioxide Levels" (2003).

28. D. Shendell, A. Winer, R. Weker, and S. Colombe, Indoor Air, 14, 154 (2004). https://doi.org/10.1111/j.1600-0668.2004.00235.x

29. P. Wargocki, D. P. Wyon, The Effects of Classroom Air Temperature and an Outdoor Air Supply Rate on the Performance of School Work by Children (Indoor Air proceeding. Danish Technical Research, 2006).

30. D. I. Sidorin, Geofizicheskie Protsessy i Biosfera 14, 67 (2015).

31. S. Gaihre, S. Semple, J. Miller, S. Fielding, and S. Turner, J. Sch. Health 84, 569 (2014). https://doi.org/10.1111/josh.12183

32. O. A. Seppänen, W. J. Fisk, and M. J. Mendell, Indoor Air 9, 226 (1999). https://doi.org/10.1111/j.1600-0668.1999.00003.x 